\title{
Penerapan Pembelajaran Menulis Puisi Dengan Teknik Kata Kunci
}

\author{
Abdul Muktadir \\ Fakultas Keguruan dan Ilmu Pendidikan \\ abdulmuktadir@unib.ac.id \\ Nady Febri Ariffiando \\ Fakultas Keguruan dan Ilmu Pendidikan \\ ariffiandonady@unib.ac.id
}

\begin{abstract}
Penelitian ini bertujuan untuk meningkatkan keterampilan menulis puisi dengan menggunakan teknik kata kunci. Metode penelitian dilakukan adalah PTK yang berdaur silkus melalui prosedur perencanaan, pelaksanaan, observasi dan refleksi. Subjek penelitian adalah mahasiswa S2 PGSD semester I. Data penelitian adalah tes, pengamatan dan dokumentasi. Instrumen yang digunakan adalah lembaran observasi mahasiswa, lembar penilaian keterampilan. Data hasil observasi akan dianalisis secara deskriptif, data hasil tes dianalisis menggunakan rata-rata. Hasil penelitian menyimpulkan: 1) Langkah-langkah penerapan teknik kata kunci dapat meningkatkan proses hasil pembelajaran menulis puisi mahasiswa, 2) Pemilihan tema menulis puisi berdasarkan lingkungan pembelajaran memudahkan mahasiswa dalam menuangkan idenya.
\end{abstract}

Kata kunci : Teknik Kata Kunci, pembelajaran, menulis, puisi

\section{Pendahuluan}

Menulis puisi merupakan salah satu keterampilan yang harus dimiliki mahasiswa S2 pendidikan dasar sebagai guru yang telah mengajar di sekolah dasar. Disamping menulis puisi, mahasiswa juga harus mampu melaksanakan pembelajaran menulis puisi di sekolah sebagaimana SK dan KD yang telah dituangkan dalam kurikulum. Tetapi pada kenyataannya di lapangan apresiasi mahasiswa terhadap karya puisi masih tergolong rendah. Mereka kesulitan untuk menuangkan perasaannya ke dalam puisi. Hal ini disebabkan karena metode yang digunakan selama ini kurang mampu mengeksplor imajinasi mahasiswa sehingga kurang mampu merangkai kata-kata menjadi puisi.

Apresiasi puisi mahasiswa yang rendah membuat mereka tidak berminat untuk melakukan pembelajaran puisi ketika menjadi guru di sekolah dasar. Pembelajaran puisi dianggap sulit untuk dilakukan sehingga meteri puisi sering kali diganti 
dengan materi lainnya atau pembelajaran puisi tetap dilakukan dengan berbagai kelemahan. Guru memiliki keterbatasan dalam merancang pembelajaran khususnya dalam memilih metode, menentukan sumber belajar dan melakukan evaluasi dalam pembelajaran puisi. Kelemahan yang terjadi dalam pembelajaran menulis puisi di SD mengakibatkan keterampilan menulis puisi siswa menjadi rendah.

Berdasarkan hasil penelitan dalam jurnal yang dilakukan oleh Ardiansyah dkk (2018), tentang meningkatkan keterampilan menulis puisi bebas menggunakan teknik pancingan kata kunci di kelas 5 SD, menunjukan Keterampilan awal siswa tentang menulis puisi bebas di kelas eksperimen dan kelas kontrol memiliki nilai signifikasi yang berbeda. Untuk nilai signifikasi kelas kontrol normal dan untuk nilai signifikasi kelas eksperimen tidak normal.

Rendahnya kemampuan siswa dalam menulis puisi terjadi karena guru belum mampu memilih teknik yang tepat untuk mengajarkan cara menulis puisi, sehingga siswa merasa bosan dan kurang bersemangat dalam menulis puisi. Menulis puisi membutuhkan imajinasi yang tinggi dan kemampuan siswa dalam merangkai kata demi kata sehingga menjadi rangkaian kata-kata yang indah. Kemampuan tersebut pada umumnya belum dikuasai sepenuhnya oleh siswa karena pembelajaran puisi belum dilaksanakan secara maksimal, terutama dalam membangun daya imajinasi siswa untuk berkreasi dalam proses menulis puisi. Untuk mengatasi kesulitan siswa memulai menulis puisi dapat diatasi dengan menggunakan teknik kata kunci. Teknik kata kunci yang digunakan merupakan teknik yang dapat membantu siswa untuk mencari gagasan dan menciptakan kata-kata awal dalam sebuah puisi.

Hal ini sejalan dengan pendapat Susanto (2013:93) menyatakan bahwa ada beberapa kelemahan-kelemahan yang yang ditemukan di lapangan yakni: a) teknik pembelajaran dominasi ceramah, b) siswa hanya dijadikan objek pembelajaran,c) pembelajaran yang berlangsung cenderung tidak melibatkan pengembangan pengetahuan siswa, karena guru selalu mendominasi pembelajaran (teacher centered), akibatnya proses pembelajaran sangat terbatas, sehingga proses pembelajaran hanya diarahkan pada pengetahuan (learning to know).

Berdasarkan pra-penelitian melalui observasi dan wawancara yang dilakukan oleh peneliti dengan guru kelas pada pembelajaran bahasa Indonesia di Kota Bengkulu yang masih menggunakan Kurikulum 2006 diketahui dalam menulis puisi bebas, siswa masih terdapat kesulitan yang mempengaruhi nilai menulis puisi siswa. Hal ini disebabkan oleh rendahnya kemampuan menulis siswa dalam menulis bebas, sehingga siswa membutuhkan waktu yang cukup lama melebihi jam pembelajaran bahasa Indonesia. Selain itu, dalam pembelajaran menulis puisi guru belum mampu menggunakan teknik yang menuntun siswa menunagkan ide dengan mudah.

Teknik dalam pembelajaran menulis puisi sangat banyak yang dapat dilakukan, salah satunya dengan penggunaan teknik kata kunci sehingga mampu membantu guru dalam menyampaikan materi puisi secara inovatif. Dengan menggunakan teknik kata kunci dapat membuat siswa tertarik dan antusias, maka peneliti berkolaborasi dengan guru kelas dengan menerapkan teknik kata kunci dalam pembelajaran menulis puisi.

Demikian pula dengan Suyatno (2010: 73), “mengemukakan bahwa pembelajaran dengan menggunakan kata kunci bertujuan agar siswa dapat menentukan kata yang dapat mewakili isi bacaan atau isi tulisan. Saat diberikan satu lembar tulisan, siswa dapat memaknai tulisan tersebut dengan minimal lima kata. Misalnya setelah siswa diberikan tulisan Jakarta, siswa langsung menuliskan kata kemacetan, kumuh, banjir, polusi, dan sibuk. Kemudian dalam pembelajaran menulis puisi kata kunci dapat merangsang kosa kata. Dengan kata kunci juga siswa dapat menetukan pilihan kata (diksi) yang tepat untuk mengekspresikan pikiran dan perasaannya dalam bentuk puisi". 
Keterampilan menulis sangat penting dalam proses pembelajaran dan harus dikuasioleh siswa. Menurut Susanto (2013:249), menulis merupakan yang sifatnya berkelanjutan sehingga pembelajaranya pun perlu dilakukan secara berkesinambungan sejak TK. Sebelum menulis, seseorang harus bisa memahami terlebih dahulu pengertian menulis. Menurut Suparno \& Yunus (2003: 23) Menulis merupakan keterampilan berbahasa aktif. Menulis merupakan keterampilan yang sangat komplek, karena menuntut ide dan kaidah bahasa.

Keterampilan menulis mencakup menulis puisi dan merupakan bagian dari kompetensi yang harus dimiliki siswa SD, seperti tertera dalam Standar Kompetensi Kurikulum 2006 kelas V. Wisang (2014: 60-62), menyatakan bahwa menulis puisi selalu berkaitan dengan kemampuan mengolah daya kreativitas dalam diri seseorang. Untuk dapat menulis puisi sesuai ketentuan (unsur pembangun puisi), beberapa langkah berikut dapat dijadikan petunjuk (Wisang, 2014: 64-68) yakni : 1) menentukan Tema, 2) menentukan Judul, 3) menggunakan Imajinasi, 4) pemilihan kata, 5) pemanfatan Majas.

Dalam pembelajaran menulis puisi, hal pertama yang perlu diperhatikan siswa adalah menentukan gagasan atau tema puisi. Tema puisi harus ditentukan terlebih dahulu karena tema puisi dijadikan sebagai acuan untuk mengemukakan isi hati penulis puisi. Tema puisi dapat diperoleh dari lingkungan sekitar. Gagasan pokok atau tema yang telah ditentukan dikembangkan menjadi baris-baris dalam puisi dan baris-baris dikembangkan menjadi bait puisi.

Salah satu teknik dalam menulis puisi dalah teknik kata kunci, merupakan teknik dengan diberikan beberapa kata kunci, kemudian kata kunci tersebut dikembangkan sehingga kata-kata itu menjadi sebuah karangan. Kemudian kata kunci dapat merangsang daya kreasi siswa yang dijadikan sebagai pangkal untuk menggali pilihan kata yang dimiliki oleh siswa.

Ada pun cara penerapannya sebagai berikut : (1) Guru memberikan pengantar, (2) Siswa membentuk kelompok, (3) Guru memberikan lembar tulisan, (4) Siswa mengidentifikasi tulisan dan menentukan tema, (5) Setelah mengidentifikasikan, siswa mendiskusikan kata kunci yang cocok dengan tulisan minimal 5 kata, (6) siswa menjabarkan kata kunci (7) siswa menulis puisi berdasarkan kata kunci yang dipilih, (8) Siswa menarik kesimpulan dari aktivitas yang mereka lakukan, dan (9) Guru merefleksikan pembelajaran pada hari itu.

\section{Metode Penelitian}

Penelitian ini adalah penelitian tindakan kelas (PTK) yang dilaksanakan secara berulang atau siklus. Setiap siklus mencakup perencanaan, pelaksanaan, observasi, dan refleksi. Penelitian ini dilakukan 2 siklus, diawali pretest untuk memperoleh pengetahuan awal mahasiswa tentang konsep kata kunci dan menulis puisi. Mahasiswa yang mengikuti pretest sebanyak 40 orang yakni kelas A sebanyak 20 orang dan kelas B sebanyak 20 orang.

Teknik pengumpulan data dalam penelitian ini adalah teknik tes, yakni tes hasil belajar menulis puisi mahasiswa. Tes dilakukan pada awal (pre-test) dan akhir proses pembelajaran (post- test). Hasil tes yang didapatkan dari penelitian ini diolah dengan menggunakan perhitungan rata-rata skor yang diperoleh mahasiswa dengan menggunakan rumus rata-rata (mean). 


\section{Hasil dan Pembahasan}

Tahap perencanaan tindakan siklus 1 tim peneliti merancang tindakan yang akan dilaksanakan. Siklus 1 dilaksanakan 2 x 50 menit satu kali pertemuan. Perencanaan tindakan yang akan dilakukan pada siklus1 adalah:

1.Tim meyusun RPP sebagai panduan dalam proses pembelajaran menulis puisi dengan teknik kata kunci.

2. Menyiapkan lembar pengamatan atau observasi pelaksanaan pembelajaran untuk setiap pertemuan untuk mengetahui proses pembelajaran.

Pembelajaran menulis puisi dengan teknik kata kunci dilaksanakan dengan langkah-langkah

1. Guru memberikan pengantar

2. Mahasiswa membentuk kelompok

3. Guru memberikan lembar tulisan

4. Mahasiswa mengidentifikasi tulisan dan menentukan tema

5. Setelah mengidentifikasikan, mahasiswa mendiskusikan kata kunci yang cocok dengan tulisan minimal 5 kata

6. Mahasiswa menjabarkan kata kunci

7. Mahasiswa menulis puisi berdasarkan kata kunci yang dipilih

8. Dalam kelas tersebut, mahasiswa membaca hasil karyanya.

9. Mahasiswa menarik kesimpulan dari aktivitas yang mereka lakukan

10. Guru merefleksikan pembelajaran pada hari itu.

Puisi-puisi yang ditulis mahasiswa dikumpulkan dan dikoreksi oleh dosen. Nilai menulis puisi mahasiswa belum mencapai capaian pembelajaran lulusan (CPL) yakni $\geq 75$. Skor rata-rata yang diperoleh mahasiswa baru mencapai nilai 60,2 (C). Perolehan nilai rata-rata tersebut merupakan gabungan empat aspek penilaian menulis puisi. Nilai empat aspek penilaian baru satu aspek yang mencapai kriteria baik yakni aspek amanat. Aspek tema, aspek diksi dan aspek pengimajian baru mencapai kriteria cukup. Skor dan kriteria untuk setiap aspek penilaian keterampilan menulis dapat dikemukakan seperti dalam tabel di bawah ini:

Tabel 1 Skor dan Kriteria Setiap Aspek Menulis Puisi

\begin{tabular}{|c|c|l|c|c|}
\hline $\begin{array}{c}\mathrm{N} \\
\mathrm{o}\end{array}$ & Aspek & \multicolumn{1}{|c|}{ Indikator } & Skor & Kriteria \\
\hline 1. & Tema & $\begin{array}{l}\text { Tema aktual, kesesuaian dengan isi puisi } \\
\text { sangat jelas. }\end{array}$ & 11.46 & Kurang \\
\hline 2. & Diksi & $\begin{array}{l}\text { Penggunaan pilihan kata sangat tepat dan } \\
\text { efektif }\end{array}$ & 13.63 & Cukup \\
\hline 3. & $\begin{array}{c}\text { Imajina } \\
\text { si }\end{array}$ & $\begin{array}{l}\text { Mengandung amanat atau pesan yang tersirat } \\
\text { yang sangat sesuai dengan tema }\end{array}$ & 15.46 & Cukup \\
\hline 4. & Amanat & $\begin{array}{l}\text { Sangat mampu mengungkapkan daya pikir } \\
\text { melalui susunan kata yang dapat } \\
\text { mengungkapkan pengalaman indrawi }\end{array}$ & 18.33 & Baik \\
\hline
\end{tabular}

Rendahnya keterampilan mahasiswa menulis puisi disebabkan mahasiswa tidak mengikuti prosedur teknik kata kunci menulis puisi. Mahasiswa tidak menjabarkan kata kunci dari tema yang dipilih. Mahasiswa langsung mengembangkan tema menjadi puisi.

Selain mengabaikan langkah-langkah penulisan puisi, tema puisi yang dikembangkan tidak bersumber dari lingkungan pembelajaran. Pengembangan tema yang tidak bersumber dari lingkungan mahasiswa menyebabkan waktu untuk menghasilkan tulisan puisi melebihi waktu yang disediakan. 
Tindakan pada siklus ke-2, 40 mahasiswa sudah memperoleh nilai $\geq 75$ atau sudah mencapai CPL. Nilai rata-rata mahasiswa untuk pembelajaran menulis puisi menggunakan teknik kata kunci dalam siklus ke-2 sudah memperoleh nilai 78 . Dengan nilai rata-rata tersebut maka terjadi peningkatan nilai dari siklus ke-1 ke siklus ke-2 sebesar 18. Perolehan nilai rata-rata tersebut merupakan gabungan empat aspek penilaian menulis puisi. Nilai empat aspek penilaian menulis puisi berada pada kriteria baik. Skor dan kriteria untuk setiap aspek penilaian keterampilan menulis dapat dikemukakan seperti dalam tabel di bawah ini:

Tabel 2 Skor dan Kriteria Setiap Aspek Menulis Puisi

\begin{tabular}{|c|c|c|c|c|}
\hline No & Aspek & Indikator & Skor & Kriteria \\
\hline 1. & Tema & $\begin{array}{c}\text { Tema aktual, kesesuaian dengan isi puisi } \\
\text { sangat jelas. }\end{array}$ & 17.54 & Baik \\
\hline 2. & Diksi & $\begin{array}{c}\text { Penggunaan pilihan kata sangat tepat dan } \\
\text { efektif }\end{array}$ & 19.34 & Baik \\
\hline 3. & $\begin{array}{c}\text { Imajinas } \\
\text { i }\end{array}$ & $\begin{array}{c}\text { Mengandung amanat atau pesan yang tersirat } \\
\text { yang sangat sesuai dengan tema }\end{array}$ & 18.46 & Baik \\
\hline 4. & Amanat & $\begin{array}{c}\text { Sangat mampu mengungkapkan daya pikir } \\
\text { melalui susunan kata yang dapat } \\
\text { mengungkapkan pengalaman indrawi }\end{array}$ & 19.35 & Baik \\
\hline
\end{tabular}

Pelaksanaan pada siklus ke-2 sudah berhasil. Keberhasilan tindakan siklus ke-2 ini dilakukan dengan perbaikan proses pembelajaran dengan menjelaskan kembali langkah-langkah teknik kata kunci menulis puisi yang harus dilakukan mahasiswa. Topik yang akan dikembangkan dalam menulis puisi pun adalah topik yang ada di ruang pembelajaran.

Perbaikan proses melalui langkah-langkah pelaksanaan pembelajaran mulai dari pendahuluan, inti, dan penutup dengan menerapkan prosedur teknik kata kunci dan penentuan tema di sekitar pembelajaran. Dalam perbaikan proses langkah-langkah menulis puisi diakhiri contoh puisi yang dikembangkan dari kata kunci topik yang dipilih bersama bersumber dari ruang pembelajaran.

Penerapan teknik kata kunci dapat meningkatkan aktivitas dan hasil belajar menulis puisi mahasiswa, karena pada pembelajaran ini nilai mahasiswa meningkat dan mencapai CPL yang telah ditetapkan. Penilitan lain juga menunjukkan hasil yang sama. Hasil penelitian Helentari, K., Heryana, N., \& Wartiningsih, A. (2016) menunjukkan adanya peningkatan keterampilan menulis puisi menggunakan media gambar dengan teknik kata kunci berdasarkan hasil tes pada siswa kelas VII I SMPBN 1 Sungai Raya yang meliputi tes siklus I dan siklus II. Hasil yang dicapai sudah memenuhi target yang ditentukan guru. Peningkatan nilai rata-rata ini membuktikan keberhasilan pembelajaran menulis puisi menggunakan media gambar dengan teknik kata kunci.

Sejalan dengan ini, Siregar, A. D. (2012) dalam penelitiannya menyimpulkan bahwa secara keseluruhan, pengajaran dengan metode pancingan kata kunci memberikan pengaruh yang positif terhadap hasil belajar menulis puisi siswa kelas VII SMP Negeri 1 Sigumpar Tahun Pembelajaran 2012/2013. Penelitian lainnya oleh Mufhidah, U. (2009) juga membuktikan pembelajaran menulis puisi dengan teknik penemuan kata kunci melalui media gambar telah berhasil meningkatkan kemampuan menulis puisi siswa kelas VII C MTs Nadhlatusy Syubban Sayung Demak.

Keberhasilan pembelajaran menulis puisi dengan teknik kata kunci dalam meningkatkan keterampilan menulis puisi mahasiswa atau siswa disebabkan oleh 
beberapa hal. Pertama mahasiswa termotivasi untuk aktif dalam menulis puisi. Menurut Helentari, K., Heryana, N., \& Wartiningsih, A. (2016) yang menunjukkan kata kunci dalam pembelajaran menulis puisi mampu membangkitkan motovasi. Perubahan motivasi membuat siswa lebih aktif dan bersemangat dalam mengikuti pembelajaran serta siswa menjadi lebih senang dengan kegiatan menulis puisi Mufhidah, U. (2009).

Kedua pembelajaran puisi dengan teknik kata kunci mampu meningkatkan aktivitas mahasiswa dalam belajar khususnya menulis puisi. Mahasiswa yang selama ini hanya menulis puisi tanpa panduan atau arahan, menjadi aktivitas menulis puisi yang lebih terarah. Helentari, K., Heryana, N., \& Wartiningsih, A. (2016) Menyebutkan pembelajaran dengan menggunakan kata kunci bertujuan agar siswa dapat menemukan kata yang dapat mewakili isi bacaan atau isi tulisan. Dalam pembelajaran menulis puisi siswa dituntut untuk menemukan kata. Kata yang dibentuk menjadi rangkaian kata yang memiliki makna. Adanya kata kunci ini akan mendorong siswa dalam menentukan pilihan kata (diksi) yang tepat untuk mengekspresikan pikiran dan perasaannya dalam bentuk puisi. Mufhidah, U. (2009) dalam penelitiannya juga membuktikan perilaku belajar siswa juga berubah ke arah yang positif.

Dalam penelitian Afrilian, Yuniar (2013) Pelaksanaan pembelajaran diawali dengan guru menjelaskan tentang langkah-langkah dalam menulis puisi. Setelah itu guru memberikan tema pembelajaran, dan menentukan kata-kata kunci secara bersamasama siswa, kemudian siswa memilih salahsatu kata kunci. Kemudian, siswa menentukan kata-kata yang sesuai dengan kata kunci. Setelah itu, kata-kata yang dipilih tersebut dikembangkan ke dalam baris puisi, diteruskan dengan menyusun baris tadi menjadi bait puisi. Selanjutnya guru dan siswa memeriksa kembali penggunaan kata-kata dan gaya bahasa. Terakhir, yaitu menentukan judul. Guru meminta salah seorang siswa membacakan hasil puisinya. Kemudian guru dan siswa melakukan tanya jawab mengenai unsure-unsur yang terkandung dalam puisi tersebut, seperti diksi, pencitraan, bunyi, judul, perasaan, dan amanat.

Pembelajaran menulis puisi seperti ini mampu meningkatkan aktivitas siswa pada setiap siklus yang dapat dilihat dari aspek yang terpenuhi. Aspek-aspek tersebut yaitu:

1. siswa menunjukkan sikap senang terhadap pembelajaran.

2. siswa menyimak penejelasan materi oleh guru.

3. siswa aktif mengemukakan pertanyaan.

4. siswa aktif menjawab pertanyaan.

5. siswa mengerjakan latihan menulis puisi.

Teknik kata kunci dapat dijadikan salah satu pilihan alternatif dalam upaya meningkatkan kemampuan menulis puisi mahasiswa ataupun siswa. Dengan teknik kata kunci, mahasiswa lebih meudah untuk mengungkapkan idenya dalam bentuk bait-bait puiei. Hal ini akan menimbulkan motivasi sehingga aktivitas belajar akan meningkat. Akhirnya keterampilan menulis puisi pun dapat ditingkatkan.

\section{Kesimpulan}

Ada beberapa hal yang menjadi simpulan dalam penelitian ini. Pertama Langkah langkah penerapan teknik kata kunci dapat meningkatkan proses hasil pembelajaran menulis puisi mahasiswa. Kedua pemilihan tema menulis puisi berdasarkan lingkungan pembelajaran memudahkan mahasiswa dalam menuangkan idenya. 


\section{DAFTAR PUSTAKA}

Akhadiah, Sabarti dkk. 1988. Pembinaan Kemampuan Bahasa Indonesia. Jakarta: Erlangga.

Afrilian, Yuniar (2013) Penerapan Teknik Kata Kunci Untuk Meningkatkan Keterampilan Menulis Puisi Siswa Kelas V Sekolah Dasar Negeri Sukajaya Kabupaten Bandung Barat. S1 thesis, Universitas Pendidikan Indonesia.

Arikunto, Suharsimi. 2006. Penelitian Tindakan Kelas. Jakarta: Bumi Aksaara.

Depdiknas, 2006. Kurikulum Tingkat Satuan Pendidikan. Jakarta: Depdiknas.

Dewi, M. S., 2017, "Pengaruh Media Gambar Terhadap Kemampuan Menulis puisi Siswa A”. Jurnal Sekolah Dasar, Vol. 2 No. Nomor ISSN : 2528-2883.

Djamarah, Syaiufudin Bahri. 2000. Psikologi Belajar. Banjarmasin: Rineka Cipta.

Helentari, K., Heryana, N., \& Wartiningsih, A. (2016). Peningkatan Keterampilan Menulis Puisi Menggunakan Media Gambar dengan Teknik Kata Kunci Kelas VII I. Jurnal Pendidikan dan Pembelajaran, 5(11).

Hodidjah, dkk. 2018, "Meningkatkan Keterampilan Menulis Puisi Bebas Menggunakan Teknik Pancingan Kata Kunci Di Kelas 5 SD". Pedadidaktika : Jurnal Ilmiah Pendidikan Guru Sekolah Dasar-vol. 5, No. 1 (2018) 43-5.

Kosasih, E. 2008. Apresiasi Sastra Indonesia, Jakarta: Nobel Edumedia.

Mufhidah, U. (2009). Peningkatan Kemampuan Menulis Puisi dengan Teknik Penemuan Kata Kunci Melalui Media Gambar Siswa Kelas VII C MTs Nahdlatusy Syubban Sayung Demak (Doctoral dissertation, Universitas Negeri Semarang).

Nurgiantoro, Burhan. 2009. Penilaian dalam Pengajaran Bahasa dan Sastra. Yogyakarta: BPFE.

Nurgiyantoro, B., 2016, Penilaian Bahasa berbasis Kompetensi (Edisi ke-2), Jogjakarta : BPFE.

Santosa, Puji dkk. 2008. Materi dan Pembelajaran Bahasa Indonesia SD. Jakarta: UT.

Sedarmayanti. 2009. Sumber Daya Manusia dan Produktivitas Kerja. Bandung: Mandar Maju

Slamet St Y. 2007. Dasar-dasar Pembelajaran Bahasa dan Sastra Indonesia di Sekolah Dasar. Surakarta: UNS Press.

Siregar, A. D. (2012). Pengaruh Penggunaan Metode Pancingan Kata Kunci Terhadap Kemampuan Menulis Puisi Siswa Kelas VII SMP Negeri 1 Sigumpar Tahun Pembelajaran 2012/2013. Basastra, 1(2).

Sudjana, Nana. 2004. Penilaian Proses Belajar Mengajar. Bandung: Remaja Rosda Karya.

Suparno \& Mohamad Yunus. 2007. Keterampilan Dasar Menulis. Jakarta: UT.

Suroso. 2007. Penelitian Tindakan Kelas Kemampuan Menulis Melalui Classroom Action Research. Yogyakarta: Pararaton.

Sutresna I. B., dkk. 2017. "Pemanfaatan Teknik kata Kunci untuk Meningkatkan Kemampuan Menulis Teks Eksposisi Siswa Kelas X MIPA 5 SMA N 1 Payangan". Jurnal Pendidikan Bahasa dan Sastra Indonesia, Vol.7 No 2.

Santosa, P., dkk. 2010. Materi Pembelajaran Bahasa Indonesia SD. Universitas Terbuka : Jakarta

Susanto, A., 2013. Teori Belajar dan Pembelajaran di Sekolah Dasar. Prenadamedia Group : Jakarta.

Syah, Muhibbin. 2010. Psikologi Pendidikan. Bandung: Remaja Rosdakarya.

Syarif, Erlina dkk. 2009. Pembelajaran Menulis. Jakarta: Depdiknas.

Tarigan, Henry Guntur. 2005, Pendidikan Keterampilan Berbahasa. Universitas Terbuka : Jakarta.

Trianto, Agus. 2014. Buku Guru Bahasa Indonesia. Jakarta: Kemendikbud.

Wardhani, Igak. 2001. Penelitian Tindakan Kelas. Jakarta: Universitas Terbuka. 
Wisang, O. I., (2014). Memahami Puisi dari Apresiasi menuju Kajian, Jogjakarta : Penerbit Ombak. 